\title{
Capacity Building for Social Innovation: A Collective Impact Approach
}

\author{
Ellen J. Szarleta
}

\begin{abstract}
Business, nonprofit, and government institutions generally agree that a vibrant economy is critical to addressing the multi-faceted, complex issues faced by urban communities. Yet, despite significant targeted efforts aimed at revitalizing economic activity over the past few decades, the state of many communities remains unchanged. A collective social entrepreneurship model, focused on building social entrepreneurial capital networks, is proposed as a complement to more traditional models focused on building individual capacity for social entrepreneurship. This article contends that one way universities can play a role in building social entrepreneurial networks is by serving as conveners. The lessons learned from a university-community initiative suggests that a collective impact framework and university leadership in a convening role, can support and inform the use of the social entrepreneurship approach to more effectively address issues of economic vitality.
\end{abstract}

Keywords: Collective social entrepreneurship; convener; wicked problem

\section{Introduction}

The issues facing communities, particularly urban communities, often elicit demands for action (Baum, 2000) and positive social change. These demands create challenges for universitycommunity partnerships grounded in relationship-building processes including divergent expectations regarding communication, decision making and authority (Prins, 2005). Addressing the immediate and pressing concerns of communities, while building mutually beneficial relationships requires more than modifying existing process; it requires innovative solutions based in systems change, e.g., such as reframing issues. The urgency to confront issues such as economic vitality provides universities and communities with an opportunity to combine the theories of collective impact and social entrepreneurship to leverage place-based knowledge to build community capacity for defining, implementing, and evaluating change.

This article examines the role of a community-university social entrepreneurship initiative in building collective capacity for long-term economic vitality. Building on the theory of collective impact, and incorporating tenets of social entrepreneurship, the early lessons of an urban farm initiative suggest that community demands can be better addressed when a network of social entrepreneurs adopts a collective impact framework. The experience also suggests that, by creating and supporting a collective approach to social entrepreneurship, the community is empowered to work toward tackling wicked problems through the lens of collective action. 


\section{The Context}

Communities in Northwest Indiana, as in many blighted, urban areas, face substantial obstacles to economic development including high rates of poverty and the loss of an industrial base. These once thriving urban areas are now recognized across the country as context for "wicked problems" (Rittel, 1973). IU Northwest, a regional campus of Indiana University, is located in Gary, a city characterized by conditions of extreme poverty and industrial decline.

Gary, IN is also burdened with conditions commonly associated with wicked problems, or problems that are resistant to resolution as a result of their characteristics (Rittel \& Webber, 1973). Rittel (1973) first characterized these types of problems with 10 or 11 properties. Conklin (2009) later condensed these wicked problem properties (2009) to six:

- The problem is not understood until you have developed a solution,

- There is no single stopping rule,

- Solutions are not right or wrong,

- Each wicked problem is unique and novel,

- Every solution is a "one-shot operation" with consequences,

- Alternative solutions are not a given.

The socio-economic conditions in the City of Gary, like those in many urban industrialized areas, set the context for a myriad of wicked problems. Approximately, 38\% of Gary's residents, $89 \%$ of which are African American, live in poverty. The city's poverty rate (Census, 2014) exceeds that of the county (18\%), the state of Indiana (15.4\%) and the United States (13.8\%). The City of Gary, founded by United Steel Corporation in 1908, was once the anchor of economic vitality in the 7-county Northwest Indiana region, and the second largest city in the State of Indiana. Gary is now the 5th largest city in the state, experiencing dramatic population losses in the last 40 years (Census, 2014). In the early decades following the city's establishment, both the city and the region were proud of their "industrial pre-eminence"- the economic foundation of prosperity (Federal Writers Project, 1939).

Today, communities take pride in resilience in the face of significant challenges. The community's resilience is evidenced in part by the number of businesses in the city; more than half of all business in Lake County, Indiana are now located in Gary (5,700 of the 9,843 businesses in the county); $69 \%$ of the city's businesses are black owned. While the number of smaller businesses is impressive, the city's economic resilience is limited by socio-demographic conditions. Per capita income (in 2013 dollars) is roughly $\$ 16,000$, or approximately $2 / 3$ of the state per capita income level. The median value of home is less than half of the median value in the state and the city's home ownership rate is $53 \%$ compared to $70 \%$ in the state. In a city of 78,000 people, 28,000 individuals make up the labor force and 25,000 are employed (Indiana labor force estimates, August 2015). Education levels of residents further limit economic opportunity. Among those aged 25 and over, only $12.3 \%$ possess a bachelor's degree, making the prospect of attracting high-earning positions to the city a significant challenge (Census, 2014).

The statistics cited above tell the story of a city plagued by factors believed to contribute to urban decline. Another statistic, the number of businesses in the city, suggests an untapped 
source of socio-economic capital that can be leveraged for urban renewal: small business. The City of Gary is home to over half of all business in Lake County, Indiana, and more than half of all businesses in the county employ 1-4 individuals (4,862 of 9,843). Small businesses are powerful agents of social change (Mair \& Marti, 2006; Aldrich \& Zimmer, 1986) and have the potential to advance local social interests previously unrecognized by larger corporations.

Yet, in the City of Gary and in the region, economic development nevertheless falters. This poses many interesting questions, including: How can community-university partnerships harness the economic potential of individual entrepreneurs to effect transformational community change? To begin answering this question, two models, social entrepreneurship and collective impact are examined.

\section{Social Entrepreneurship}

While social entrepreneurship has enjoyed wide recognition for its successes (Mair \& Marti, 2006), a widely accepted definition of the phrase in academic circles does not yet exist. Two decades ago, the literature focused on distinguishing business entrepreneurship and social entrepreneurship based on social-value creation. Venkataraman (1997) states that under business entrepreneurship, social wealth is a by-product of economic value, while the focus of social entrepreneurship is on social value creation. More recently, Seelos and Mair (2005) argue that the boundary between business and social entrepreneurship does not lie in the distinction between profit motive and altruism, but suggest that the motivation of social entrepreneurs is one of not only doing good, but also doing well and pursuing personal fulfillment.

Internationally recognized social entrepreneurship initiatives include Professor Muhammad Yunus’ work empowering women in Bangladesh. The Grameen Bank, founded by Yunus, provided credit to the poor by removing the need for collateral, and created a banking system based on trust, accountability, creativity and participation (Yunus, 2007). As of October of 2011, the Grameen Bank had 8.349 million borrowers, 97\% of whom are women. (Yunus, 2017). More recent efforts, such as Kiva, the first online peer-to-peer microcredit marketplace, facilitate entrepreneurship across the global by leveraging the financial resources of similarly minded individuals. Operating outside the United States since 2005, Kiva began funding loans to small US-based business owners in 2012, introducing a significant innovation in the field: social underwriting or banking based on character. This program has now sourced more than \$25 million in new loans (Sahni, Lanzerotti, Bilss, \& Pike, 2017)

With such generally accepted success it is clear why social entrepreneurs are seen be vital to the production of social capital. However, an important limitation of social entrepreneurship is the limited ability to capture the value that is created particularly in areas where enterprise is focused on meeting basic needs (Seelos \& Mair, 2005) as the capacity to earn profit is constrained by lower levels of income. Mair and Marti (2006) suggest that embeddedness, as a mindset, is particularly limiting in areas where the pool of resources has run dry. In such areas, the positive effects of embeddedness, e.g., the ability to leverage relationships to access resources, are outweighed by individual entrepreneurs' diminished willingness or ability to take on a challenge. Collective social entrepreneurship, an emerging concept in the literature, is one vehicle for overcoming embeddedness. 


\section{Collective Social Entrepreneurship}

Montgomery, Dacin and Dacin (2012) define collective social entrepreneurship as collaboration among stakeholders for the purpose of applying business principles to solving social problems. The value of collective social entrepreneurship, as opposed to individual social entrepreneurship, lies in its potential to bring about the institutional arrangements that will support transformative, as opposed to transformational change. These forms of change, explained below, are distinct in both their process and their outcome.

Transformational change is a familiar concept to organizations in all sectors. Strategic planning, commonly undertaken by businesses, government, and nonprofits, is one process used to effect a transformational change. This form of change is both pervasive and intentional. It occurs over a period of time and if successful, strongly influences institutional culture (Eckel \& Kezar, 2003). Notably, the outcome of this process is a change in the internal functions of an organization with the goal of supporting its historical purpose or mission. For instance, in the business sector, transformational change leads to an overhaul of strategy and organizational restructuring (Bess \& Dee, 2008); in education, transformational change may take the form of alternative methods of teaching, research and service, while preserving the institution's focus on all three areas (Holley, 2009). The frame of reference, in both cases, remains unchanged while internal functions are reorganized to improve outcomes consistent the organization's existing frame of reference.

Transformative change, on the other hand, requires the development of new frames of reference (Mezirow, 1997), or the habits of mind or points of view that help us to understand our experiences (Moore, 2005). Unlike the process of transformational change, where existing frames of reference are preserved, transformative change seeks to expand knowledge in a way that leads to new frames of reference. At the same time, the process recognizes and seeks to balance the tension between those who seek to modify existing practices to address issues as opposed to a collective reframing of the issues. A transformative change approach was recently adopted by the United Nations in developing the latest set of United Nations Sustainable Development Goals (SDGs), published in 2015. In framing the new SDGs the issues of sustainable and inclusive societies were addressed at a more fundamental level, including the questioned use of science and technology policy for meeting social needs. (Schot \& Steinmueller, 2016)

The policies emerging from the use of this frame challenge the long-held assumption that science, technology and innovation, as defined to date, are compatible with social welfare and progress. A deeper set of questions, addressing both social goals and innovation processes emerged and policy makers thinking, was broadened beyond support for R\&D while encourages the development of a greater set of views and alternatives (Schot \& Steinmueller, 2016). In sum, a transformative change frame examines systems and their embedded thinking processes. It also facilitates a deeper understanding of the interconnectedness of, for example, social and economic systems. Employing this frame in the context of wicked problems, such as SDGs, and economic vitality, provides communities and universities with an opportunity to overcome a mindset of embeddedness. 
Collective social enterprise, if well-functioning, has the capacity to create new knowledge and new frames of reference resulting in transformative learning experiences and change for communities. Community-university partnerships supportive of collective enterprise networks can leverage these experiences and move beyond incremental approaches to transformative approaches to tackling wicked problems.

However, well-functioning networks of socially minded businesses are not always present in our communities, and overcoming a mindset of embeddedness requires a willingness to think beyond individual gain. It is not enough, as is the case of businesses in Gary, to have large numbers of individual entrepreneurs functioning in a resource-limited area with a mindset of embeddedness; rather, if harnessed collectively and supported, the interests and talents of socially-minded entrepreneurs have the potential to overcome this mindset and more effectively identify and address complex, interdependent issues. Collective impact, a transformative change approach to effecting social transformation, offers one practical approach for building such networks and universities can play a role.

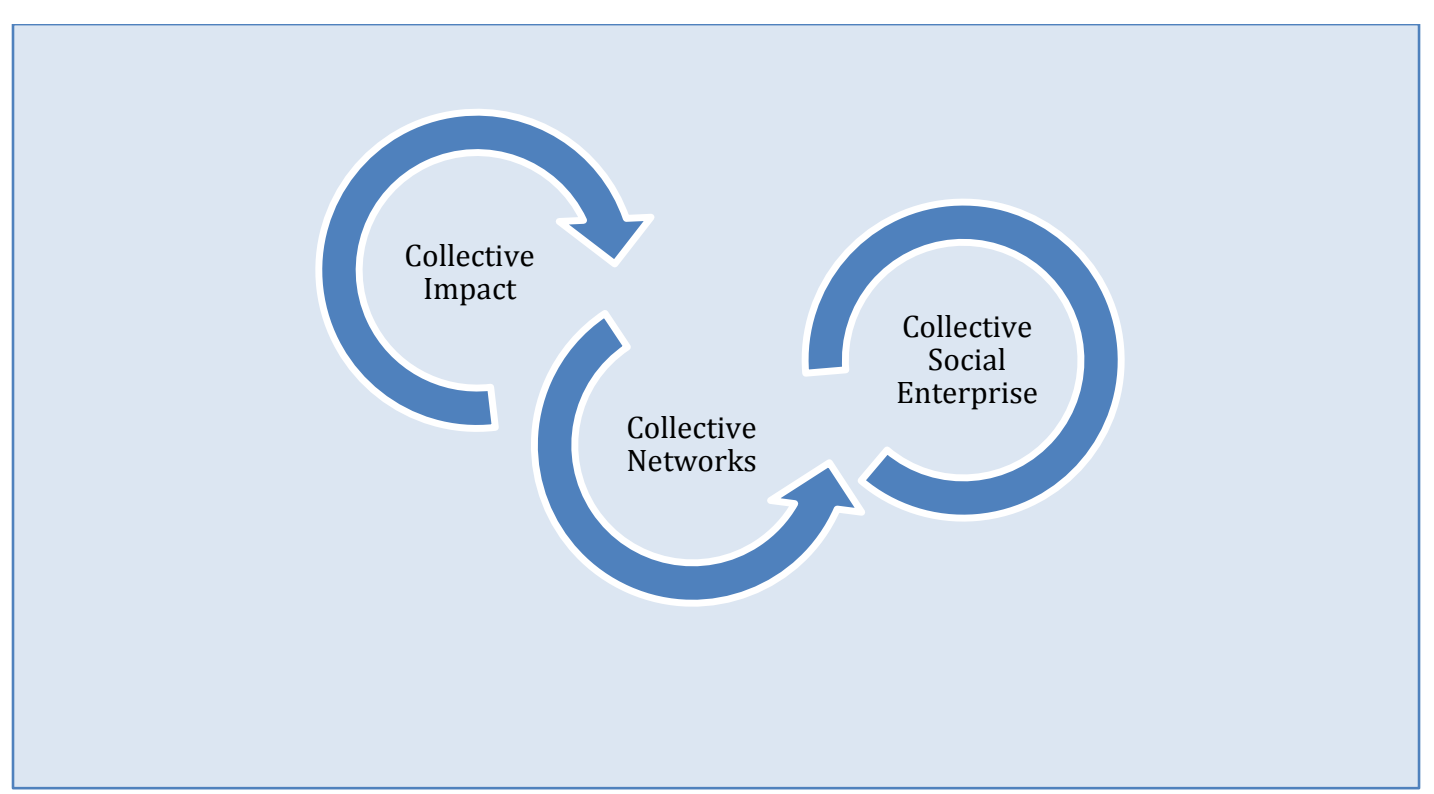

Figure 1. Collective impact in support of collective social enterprise. This figure illustrates the relationship between collective impact, collective networks, and collective social enterprise.

Collective Impact is a framework for tackling deeply entrenched and complex social problems. It focuses on making collaboration work across sectors and citizens to achieve significant and lasting social change. It calls for multiple organizations or entities to abandon their own agenda in favor of a common agenda (Kania, 2011). In the collective impact model, the process and the results are emergent and not predetermined, resources are uncovered, learning is continuous, and adoption occurs simultaneously among the organizations involved (Kania \& Kramer 2011). Conveners or backbone organizations support collective impact initiatives as they coordinate and manage participants in a manner that supports fidelity (Kania \& Kramer 2011). Their common activities include: (a) guiding the vision and strategy; (b) supporting aligned activities; (c) establishing measurement practices; (d) building public will; (e) advancing policy; and (f) mobilizing funding (Turner, Merchant, Kania and Martin, 2013). 
Engaging in these activities also brings challenges, particularly when managing networks addressing "wicked” problems. So while, as Weber and Khademian (2008) note, networks are good alternatives to existing systems for developing public policy, managers still face significant challenges. The advantages of networks, including their flexibility, efficiency and innovative ways of organizing that accomplish collective goals are documented in studies by Powell, (1988), Aldrich and Zimmer, (1986), Borgatti and Cross (2003); and Van Bueren, Klign, and Koppenjan (2003).

The literature suggests that collective impact, supports the formation of collective networks. (Figure 1). However, the literature has not significantly addressed the management of networks including the challenges that emerge when addressing "wicked problems.” Turner et al. (2013) offer insight on network management in the context of collective impact, but there work remains to be done in this area.

As noted above, collective social enterprise can be thought of as collaboration for the purpose of applying business principles to solving social problems (Montgomery, 2012). The collective impact framework and the collective social enterprise share an assumption that collective action is a vehicle for transformative change. Both embrace a social movement that challenges the existing frame of reference. They are distinct in that collective impact offers a structured approach for collaboration while collective social enterprise focuses on the application of business principles to social issues. This paper provides an example of how, together, collective impact principles and collective social enterprise concepts can be employed to address the challenge of economic vitality in urban and metropolitan areas. Specifically, the collective impact framework offers the process and structure to enable the formation of the collective networks necessary for collective social enterprise.

In this case study, we discuss how, using the collective impact model, IU Northwest has played a role in facilitating the development of a social entrepreneurship network that is in the early stages of creating a new mindset for addressing food insecurity while advancing K-12 educational experiences. The study provides an example of how the collective impact framework, supported by a university convener, fosters a network of shared knowledge and contributes to the growth of collective social enterprise.

\section{Case Study: Advancing Collective Social Enterprise}

Indiana University Northwest is a non-residential regional campus of Indiana University. The campus of more than 5,600 students is located in Gary, Indiana. It offers both undergraduate and graduate degrees in more than 70 campus and hybrid degree programs. Serving 7 counties in the northwest corner of Indiana, the campus seeks to enhance the quality of life of the most diverse, urban, industrialized region of the state (IU Northwest, 2017). The campus values collaboration with external partners, other educational institutions, and the Northwest Indiana community, and identifies community engagement as a strategic priority. As a result the campus engages in community-based collaborations supportive of research, teaching and service. 
The campus' path to advancing collective social enterprise, using the collective impact model, began more than 5 years ago. Prior to 2012, faculty with an interest in social enterprise engaged in conversations with individual entrepreneurs and business organizations, seeking information and knowledge on this new form of business practice. During the 2012-2013 academic year a more systematic exploration of social entrepreneurship was undertaken when the campus participated in the "Leadership IU" - an Indiana University leadership capacity building initiative. The IU Northwest "Leadership IU" team made up of three faculty members and four City of Gary municipal administrators, together identified a critical community need —-food insecurity - and explored the potential of social entrepreneurship models for improving economic vitality in the city. The team focused on developing a strategy for increasing awareness and understanding of the social enterprise as a way for individual businesses to meet community needs, including identifying goals and priorities related to coursework and internship opportunities. However, the initiative, while useful for building a stronger university-city relationship, remained in the planning stages.

One of the most important lessons learned from the Leadership IU initiative was that advancing individual social entrepreneurship training would require broader community support and a larger network of social entrepreneurs. Individuals and organizations, without significant resources, were unwilling take the risks essential to advancing a new form of enterprise, or as mentioned earlier, the mindset of embeddedness limited opportunity. Without significant community recognition of the need for and value of social entrepreneurship there was limited incentive for the university and the community to commit scarce resources. The Leadership IU team determined that a broader base of support was needed and alternative models, including those of collective social entrepreneurship should be explored. The campus continued this work by broadening a campus-secondary education partnership in the area of urban farming, to explore the development of a collective social enterprise.

Food Insecurity: Growing K-12 Social Entrepreneurs

The initiative began with a school-based 4-H garden project. In 2013, the director of an afterschool 4-H urban garden project approached the campus seeking guidance on ways to connect the 4-H garden project to science and math learning objectives in elementary and middle school classes. A pilot project was implemented, and teachers soon began the process of integrating garden activities into their academic lessons. Soon thereafter, teachers, administrators, parents and community members became increasing aware of the food and nutrition needs of students and the community. The project expanded quickly, and the $4-\mathrm{H}$ program acquired poultry in the second year, despite the lack of housing for hens. Momentum for the expansion of the garden into an urban farm had taken hold.

In the midst of increased community and school interest in addressing food insecurity, and student learning through an urban farm initiative, the campus remained engaged in the process of partnership building including, at one point temporarily providing needed space for farm activities. This show of commitment by the campus opened the door to the next phase of the project: the creation of collective social entrepreneurship network that would support transformative change in the school and in the community. The University: The Collective Impact Model 
Defining the university's role in building the collective social entrepreneurship network required reflection and planning. Specifically, a formal evaluation of stakeholder readiness to move beyond collaboration to collective impact was undertaken. The first step required an assessment of the initiative's readiness for collective action. O’Neil and Griffiths (2011) suggest there are 5 types of assessments that can assist in determining readiness. The choice of an assessment method depends on many factors including the type of information available and resources that can be expended to advance the initiative. Often what is assessed is the initiative's readiness for the five elements of a successful collective impact initiative. These five elements are:

- Common agenda,

- Shared Measurement,

- Mutually reinforcing activities,

- Continuous communication, and

- Backbone support.

Assessing the readiness of the 5 common elements begins with an examination of the common agenda, commencing with the questions, "what exists among the partners?" and "what is desired?” In the present case, the emerging social partnership members included the charter school (teachers and administrators), 4-H program leaders and administration, university faculty and administration local business representatives, and interested community members including the school's founder. We observed signs of effective organizational pairing, a phenomenon consistent with successful partnership formation (Seitanidi, Koufopoulos, \& Palmer, 2010) and agenda setting. Successful pairing originates in early interactions that are sustained over time. Collaborating organizations, as in the instance case, do not rush into the partnership in order to capitalize on partnership benefits while overlooking costs. The university, for instance, was engaged on a limited basis (e.g., occasional meetings, hosting poultry) for more than one year, prior to providing formal training on social entrepreneurship and engaging in program development.

The literature also suggests that effective pairing requires participants to engage in systematic planning and preparation (Jamali \& Keshishian 2009) in the development of mutually reinforcing activities. In the present case, the partners had in fact invested time in the process of identifying organizations with the potential to develop a shared common agenda bringing different but essential sets of resources to the table (Seitanidi et al., 2010). This method of tacit partnership formation is an indicator that the initiative was ready for a collective impact approach to building social entrepreneurship networks. The activities undertaken, including a social entrepreneurship workshop for students and business community members, combined university-school-business resources in an effort to increase awareness and build interest in collective social enterprise, while fostering the development of a social enterprise network.

The researcher, using the five conditions of successful collective impact initiatives as a guide, undertook an assessment of the initiative's readiness for action. After reviewing information and consulting the partners it was determined that 3 of the 5 conditions were present: (a) the partners engaged in continuous conversations over a two-year period; (b) they developed a common agenda to address food insecurity and K-12 business learning; and (c) participated in mutually 
beneficial activities over the course of their engagement. Two conditions however, were not yet satisfied: backbone support was limited, and shared measurement was not occurring. Significant challenges lie ahead, but the role of the university also became clear, and a decision made to support the initiative in the role of convener.

\section{The University: Backbone Organization}

The need for a backbone organization and for shared measurement could be met if the university transitioned from collaborator to convener. If the university were to embrace the role as convener, it needed to take responsibility for the six activities identified by Turner, Merchant, Kania and Martin (2013) as common to backbone organizations:

- Guide vision and strategy,

- Support aligned activities,

- Establish shared measurement practices,

- Build public will,

- Advance policy, and

- Mobilize funding.

To determine university's readiness for assuming the role, the researcher conducted a review of the university's convening role in prior community-university initiatives. The University's community engagement center, over time, had successfully served as a leader in 5 of the 6 activities, including guiding vision and strategy, establishing shared measurement practices, building public will, advancing policy and mobilizing funding. In many cases, our involvement consisted of a subset of these activities, e.g., in a recent community-building project the university facilitated visioning and strategy sessions while building public will. However, serving as a convener meant expanding our role and breaking new ground. The university in this role would assume the full set of activities. In addition, resources would be dedicated to developing the capacity to support partner-aligned activities.

The university realized this to be a significant challenge, particularly in the face of a long tradition of balkanized local government, competition among nonprofit organizations, and a staunchly market-based private sector orientation. This was also, however, an opportunity to build community capacity to overcome these barriers with the support and interest of the partners in the urban farm initiative, and align a collective social enterprise network, which would be essential for transformative change to take place in the region. Effectively supporting the aligning activities of the partners would not only help accomplish more specific objectives for the initiative. It would also foster a network of social entrepreneurs that, over time, would create new social and economic infrastructure.

The first opportunity for alignment came in the area of collective education and awareness. A workshop, created by the university's community-university engagement center, brought together small business leaders with charter school students studying social entrepreneurship. The workshop goal was to help build a collective network of experienced business professionals wanting to explore social enterprise concepts, with youth learning about social enterprise in and educational setting. Noting that the best social alliances involve intensive educational efforts and 
require learning on the part of both partners, (Berger, Cunningham, \& Drumwright, 2004) The university designed the workship to foster the reciprocal transfer of, on the one hand, practical small business development skills, and on the other, deep insight on and experiences with wicked problems facing youth. The motivation of both of these groups was to improve the overall quality of life in the community through innovative approaches, and effective alignment supported these intentions.

The workshop served to bring two groups together that might not otherwise recognized a shared interest, while building the collective capacity of the network. Approximately 30 people attended, the majority of whom were high school students. Together, teams of students worked with a small business owner to develop a new social enterprise concepts or, alternatively, provide feedback on existing ideas for addressing pressing social concerns with business methods. Feedback from the workshop was obtained. Participants welcomed the opportunity to interact with one another. Business leaders found inspiration in student ideas, and students valued the experience of local business leaders. These observations are supported by the results of a survey of participants.

As a result of the workshop's success, the local chamber of commerce financially supported a social entrepreneurship training workshop open to the business community, providing education to an even larger and more diverse set of potential business partners. The university's effective support took the form of organizational planning, space, and relationships, of school-business sector activities. This in turn helped spur the development of a social entrepreneur's network that could work to create a strategic plan, one that would set specific goals for expanding the urban farm while deepening student learning in high school business classes.

Strategic planning provided a second opportunity to align partner activities. The success of the previous workshops and classroom activities, as well as strong community interest, led to the request by community partners to develop a strategic plan. From the beginning of the strategic planning process, the university recognized that cross sector collaborations are complex, consisting of inherent contradictions (Kanter, 1999), and fraught with conflicts resulting from incompatible objectives, ideas and values (Selsky \& Parker, 1997). However, a review of participating organization missions suggested that realizing shared values and a shared vision would be possible. The organization mission/purpose statements contained phrases such as, “develop a sense of reciprocal obligation," “develop the knowledge, skills, work attitudes and habits," "foster local and regional economic development," and "prepare young people to be leaders in their community...through hands-on experiences.”

The process began with a visioning session—often a challenge in well-formed organizations. However, in this case, facilitation by the university not only brought the core group of partners together, but also revealed a need to expand the network. In an initial meeting of five partners, a vision statement was created and later shared with the leadership of each of the individual organizations. As the partners had been working together on separate but related small-scale initiatives, the visioning process essentially was a formalization of the shared interests expressed publically as a collective social enterprise. Each representative participant was then able to take back to their organization a vision for social change, which could be used to encourage choices 
leading to transformative actions. Martin (2000) identifies this type of organizational transformation as one mode of social change.

Simultaneously, over the course of the next year, momentum for the urban farm grew and the high school business enterprise class formed a student-run business. Students leveraged existing business relationships and established connections with local businesses in need of fresh eggs; a fledgling collective social enterprise was formed. The strategic plan, facilitated by the university, identified key partnerships that would be required to sustain the social enterprise, as well as an approach to integrating learning objectives associated with team building and leadership into the business curriculum.

Thus, the support provided by the university, serving as a convening backbone organization, permitted the partners to navigate the complex obstacles of boundaries both between and within organizations. By convening a network of individuals and organizations interested in creating a strategic plan, the university enabled its partners to focus on bringing resources, knowledge, and expertise to the table. They identified unique solutions and explored whole-system innovations, such as student-based social enterprise embedded in a high school curriculum. The university's role as a convener was to champion the initiative, in a way that permitted partners to navigate both internal and external obstacles and boundaries (Dorado \& Vaz, 2003).

In the present case, the university's support in the planning and community education and awareness obstacles contributed to the initiative's success in the initial critical stages of collective enterprise formation. Even with the support of the university, the process of network creation, both internally and externally continues to be challenged by the disparate views of stakeholders and competing goals and priorities. In the context of a wicked or complex social problem, the convener serves to convince others to address issues jointly, initiate challenge and build social capital (Dorado, 2005; Svendsen \& Laberge, 2005). This role is vital to collective social entrepreneurship.

\section{Lessons Learned}

In the present case study, the seeds of transformative change initially lay in the hands of a small number of passionate local leaders seeking to address a wicked problem characterized by urban food insecurity and the need to improve K-12 educational experiences. The loose affiliation of participants, and absence of experience in social entrepreneurship and network building, limited the partner's ability to move forward. After careful review of available resources, as well as an assessment of the benefits and challenges of university participation, the university determined that it might best serve as a convener.

Conveners build the community's capacity to define issues, identify innovative solutions, and implement a coordinated approach to addressing community concerns. Universities possess the skills, knowledge and expertise to undertake initiatives (often without community participation), but a transformative approach requires a different frame of reference. As a convener, the campus assumed the role of capacity builder. It supported partners as they sought to identify and facilitate collective activities, create networks, engage in transformative change, and ultimately seek social progress. This role employed the existing skills and resources of the university, e.g., 
facilitation, critical thinking, while also providing opportunities for research and student learning.

This initiative is a first step in improving our understanding the university's role as convener for collective social enterprise. From the experience, we also learned that by borrowing key concepts from collective social entrepreneurship and collective impact models an environment characterized by conditions that support transformative change can be created. These conditions include:

- Clearly identified community-identified needs,

- Socio-political infrastructure,

- Community education efforts focused on the topic of collective impact,

- Community willingness to adopt a collective impact model, and

- Support from university institutional leadership.

To build a network supportive of transformative change, it was helpful to assess the challenges posed to managers of "wicked" problems. These challenges have been categorized as: (a) the need for a broad knowledge bases from both inside and outside of the network; (b) the need to develop useable new knowledge to solve problems; (c) the need to create shared knowledge that facilitates cooperation and the continuous transfer, receipt and integration of knowledge that supports the development of long-term problem-solving capacity (Weber \& Khademian 2008). It is this last challenge - the creation of shared knowledge - that points to the need for the development of long-term problem-solving capacity that focused the work in this case study.

It also provided the university with the opportunity to identify a new role in community engagement initiatives. Through a process of critical reflection, universities can compare their capacity to the long-term problem-solving capacity identified by Weber \& Kahdemian (2008) as necessary for transformative change. The case study provides one example of how a campus engaged in a process of critical reflection, and arrived at a decision to serve as a convener, in the context of "wicked" problems. It is also important to note that the campus recognizes the need to further explore the potential for serving in this role in the future and to evaluate our effectiveness.

In the instant case, the campus assumed the role of convener, facilitating the collective's functioning as opposed to serving in the role of partner. Conveners build capacity. Partners work is focused directly on addressing the wicked problem (e.g., food insecurity or K-12 educational improvements). By contrast, the role of convener is focused on building the capacity of the partners to address the wicked problems through collective action. Acting as facilitator for the collectives' functioning positioned the university as a convener and collective capacity builder. What was learned in the present case is that regional universities can assume either role. In the past, the campus efforts were dedicated to partnering with the communities and sharing expertise, financial and other resources. In the present context, the university engaged in activities that supported network building, while the community partners defined problems and identified solutions collaboratively. 
What is known is that the absence of effective backbone support from conveners is the number one reason why collective impact initiatives fail (Turner et al., 2013). Community-based research and teaching clearly can place (and has placed) the university in the role of partner. Higher education has successfully participated in mutually beneficial and reciprocal relationships that have transformed communities. This article suggests that by using the collective impact model to guide activities in the role of convener, universities can be employed in an alternate way-not as a partner, but as a collective capacity builder. Universities serving in the role can realize benefits and face challenges.

As a convener, universities can find rich opportunities for research, teaching, and service. Conveners are in a unique position of providing not only the support needed, but determining the type of support that will best advance the participants' collective goals. Researchers can contribute to a plethora of emerging topics, because the work in collective impact and collective social enterprise is relatively recent, and many issues remain to be explored. For example, there is room to contribute to conversations on whether or not social entrepreneurship is a discipline, on the role of social entrepreneurship networks in promoting long-term change, and on the value of applying a collective impact framework in the social entrepreneurship context. Students, guided by faculty can examine and participate in the role of convener acquiring skills in listening, facilitation, needs assessment, and project management and implementation. Ultimately, these experiences can enrich and inform the community-university relationship for the benefit of both partners.

The case study explores a regional university's approach to assessing the potential for and usefulness of this model for advancing social entrepreneurship in the context of "wicked problems." We assert that this framework is not only useful to understanding the challenges of network management, but also to the assessing a regional institution's role as a convener/network manager. Significant work, however, remains. For example, additional studies could be conducted exploring the university's success in the convener role, including assessment of the conditions for institutional readiness, and how its effectiveness would inform decision making and implementation.

Social entrepreneurship, or innovation focused on solving a social problem, or "social capitalism” can offer opportunities for revitalizing communities. Currently, however, the capacity for social entrepreneurship and capacity-building efforts are limited in Northwest Indiana. Increasing awareness and knowledge of social entrepreneurship will both be important to economic revitalization, and to long-term economic vitality.

\section{Next Steps}

The collective impact model provides a framework for universities as they assume the role of backbone organizations in collective social enterprise (Axelrod \& Dubb, 2010). In this case, the work is firmly entrenched in the early stages of applying the collective impact model, guiding vision and strategy, and simultaneously supporting aligned activities towards addressing the wicked problem of food deserts and economic vitality. In the next phase of the work, the campus will identify best practices for supporting aligned activities emerging from the collective social enterprise network as well as assessing the existing social enterprise network capacity. To date, 
the activities identified by the network in support of collective social enterprise include developing a full-scale urban farm plan, as well as spinoff businesses e.g., a student-run restaurant. One longer-run goal is to develop, in collaboration with the university, a high school/university curriculum that supports learning in support of sustainability principles. A pilot curriculum project was conducted in the spring of 2017.

As a convener, the campus will continue to identify and implement methods of building network capacity. One proposed activity is to have the network develop shared measurement practices for outcomes and indicators. The university will guide the network through this process while simultaneously identifying funding opportunities. This interconnected process assists partners in understanding the value of shared measurement, not only for the purposes of improving process and outcomes, but also for obtaining the financial resources so needed in addressing "wicked problems.”

\section{Conclusion}

Transformative change can and should be supported by the community-engaged universities located in environments beset by the "wicked" problems of both urban decay and economic stagnancy, particularly when these environments contain limited social and human capital. The literature from the fields of social enterprise, collective social enterprise and collective impact informs development of innovative approaches to transformative change-specifically the development of networks.

As is evidenced in the literature (Hausmann, 2015; Heinze, Banaszak-Holl \& Babiak, 2016; Phillips, Lee, Ghobadian, O’Regan \& James, 2015), social entrepreneurship networks can provide tools to communities seeking to address economic and social issues. The structures inherent in such networks support interactions that provide the social mechanisms needed to lower the probability of failing and enable the knowledgeable actors to change structures, (Hausmann, 2015) thus facilitating transformational change. These networks ultimately simulate collective impact and sustainable social innovation (Hausmann, 2015).

The value of conveners to these networks is unmistakable. Collective impact participants believe that without these organizations, the collective would revert back to a small group of stakeholders making decisions for the community (Hanleybrown, Kania, \& Kramer, 2012). Particularly in the early stages of collective impact initiatives, backbone organizations play an important role in guiding vision and strategy, while supporting aligned activities (Hanleybrown et al., 2012). Collective social enterprise initiatives, as relatively recent developments in social change practice, may lack the resources and capacity to collectively develop vision, strategy, and support the activities chosen to effect social change. Collective impact offers the university a role in the process, consistent with a university’s expertise and knowledge.

This paper suggests that a systematic method of determining the readiness of a university to serve as a convener of collective social enterprise networks can lead to valuable contributions to addressing "wicked” problems. By supporting the alignment of collective activities, as determined in a cross sector partnership, and subsequently changing its role through the collective impact process, the university can assist in developing the social capital that is often 
missing when undertaking transformative change. This initiative, in the early stages of the collective impact process, will result in a collection of lessons that can be shared to better inform and build the university's capacity to serve as a backbone organization for social capital capacity building. 


\section{References}

Axelroth, R., Dubb, S. (2010). The Road Half Traveled: University Engagement at a Crossroads. Retrieved from http://community-wealth.org/sites/clone.communitywealth.org/files/downloads/report-axelroth-dubb.pdf

Baum, H. S. (2000). Fantasies and Realities in University-Community Partnerships. Journal of Planning Education and Research , 20, 234-246. https://doi.org/10.1177/0739456X0002000208

Berger, I. E., Cunningham, P. H., \& Drumwright, M. E. (2004). Social alliances: Company/nonprofit collaboration. California management review, 47(1), 58-90. https://doi.org/10.2307/41166287

Bess, J. L., \& Dee, J. R. (2008). Understanding college and university organization: Dynamics of the system (Vol. 2). Stylus Publishing, LLC.

Borgatti, S. P., \& Cross, R. (2003). A relational view of information seeking and learning in social networks. Management science, 49(4), 432-445.

https://doi.org/10.1287/mnsc.49.4.432.14428

Conklin, J. (2009, Winter). Building Shared Understanding of Wicked Problems. Rotman Magazine (Winter), pp. 17-20.

Dorado, S. (2005). Institutional entrepreneurship, partaking, and convening. Organization studies, 26(3), 385-414. https://doi.org/10.1177/0170840605050873

Dorado, S., \& Vaz, P. (2003). Conveners as champions of collaboration in the public sector: A case from South Africa. Public Administration and Development, 23(2), 141-150. https://doi.org/10.1002/pad.270

Eckel, P. D., \& Kezar, A. J. (2003). Taking the reins: Institutional transformation in higher education. Greenwood Publishing Group.

Federal Writers Project, the Calumet Region Historical Guide. (1939). Complied by the Workers of the Writers Program of the W.P.A.

Hanleybrown, F., Kania, J., \& Kramer, M. (2012). Channeling change: Making collective impact work. Stanford Social Innovation Review, 20(1). Retrieved from

https://ssir.org/articles/entry/channeling_change_making_collective_impact_work

Hausmann, R. C. (2015). Organizing Ecosystems for Social Innovation: The Relationality of Contexts and Mechanisms in a Social Entrepreneurship Network (Doctoral dissertation, The George Washington University).

Heinze, K., Banaszak-Holl, J., \& Babiak, K. (2016). Social Entrepreneurship in Communities. Nonprofit Management and Leadership, 26(3), 313-330. https://doi.org/10.1002/nml.21198 
Holley, K. A. (2009). Interdisciplinary strategies as transformative change in higher education. Innovative Higher Education, 34(5), 331-344. https://doi.org/10.1007/s10755-009-9121-4

Indiana Labor Force Estimates (2015 August). Retrieved from

http://www.in.gov/activecalendar/EventList.aspx?fromdate=9/1/2015\&todate=9/30/2015\&displa $\mathrm{y}=$ Day\&type=public\&eventidn=231631\&view=EventDetails\&information_id=220574

IU Northwest. (2017). Mission - Indiana University Northwest . Retrieved August 29, 2017, Retrieved from http:///www.iun.edu/mission

Jamali, D., \& Keshishian, T. (2009). Uneasy alliances: Lessons learned from partnerships between businesses and NGOs in the context of CSR. Journal of business Ethics, 84(2), 277-295. https://doi.org/10.1007/s10755-009-9121-4

Kania, J., \& Kramer, M. (2011). Collective impact.

Kanter, R. M. (1999). From spare change to real change: The social sector as beta site for business innovation. Harvard business review, 77(3), 122-133. Retrieved from https://hbr.org/1999/05/from-spare-change-to-real-change-the-social-sector-as-beta-site-forbusiness-innovation

Mair, J., \& Marti, I. (2006). Social entrepreneurship research: A source of explanation, prediction, and delight. Journal of world business, 41(1), 36-44.

https://doi.org/10.1016/j.jwb.2005.09.002

Martin, R. (2000). Breaking the code of change, 453.

Mezirow, J. (1997). Transformation theory out of context. Adult Education Quarterly, 48(1), 6062. https://doi.org/10.1177/074171369704800105

Moore, J. (2005). Is higher education ready for transformative learning? A question explored in the study of sustainability. Journal of transformative education, 3(1), 76-91. https://doi.org/10.1177/1541344604270862

Montgomery, A. W., Dacin, P. A., \& Dacin, M. T. (2012). Collective social entrepreneurship: Collaboratively shaping social good. Journal of Business Ethics, 111(3), 375-388. https://doi.org/10.1007/s10551-012-1501-5

O’Neil, C. \& Griffiths, S. (2011, October) Collective Impact Readiness Assessments. Retrieved from http://vibrantcanada.ca/files/collective_impact_readiness_assesssments.pdf

Phillips, W., Lee, H., Ghobadian, A., O'Regan, N., \& James, P. (2015). Social Innovation and Social Entrepreneurship: A Systematic Review. Group and Organization Management, 40(3), 428-461. https://doi.org/10.1177/1059601114560063 
Prins, E. (2005). Framing a Conflict in a Community-University Partnership. Journal of Planning Education and Research, 25(1), 57-74. https://doi.org/10.1177/0739456X04270370

Raab, J., \& Milward, H. B. (2003). Dark networks as problems. Journal of public administration research and theory, 13(4), 413-439. https://doi.org/10.1093/jopart/mug029

Rittel, H. W., \& Webber, M. M. (1973). Dilemmas in a general theory of planning. Policy sciences, 4(2), 155-169. https://doi.org/10.1007/BF01405730

Roberts, N. C. (1992). Roberts: public entrepreneurship and innovation. Review of Policy Research, 11(1), 55-74. https://doi.org/10.1111/j.1541-1338.1992.tb00332.x

Sahni, N., Lanzerotti, L., Bliss, A., \& Pike, D. (2017, August 1). Is Your Nonprofit Built for Sustained Innovation? Stanford Social Innovation Review. Retrieved from https://ssir.org/articles/entry/is_your_nonprofit_built_for_sustained_innovation

Schot, J., \& Steinmueller, W. E. (2016). Framing Innovation Policy for Transformative Change: Innovation Policy 3.0. Sussex, UK: Science Policy Research Unit - University of Sussex.

Seelos, C., \& Mair, J. (2005). Social entrepreneurship: Creating new business models to serve the poor. Business horizons, 48(3), 241-246. https://doi.org/10.1016/j.bushor.2004.11.006

Seitanidi, M. M., Koufopoulos, D. N., \& Palmer, P. (2010). Partnership formation for change: Indicators for transformative potential in cross sector social partnerships. Journal of Business Ethics, 94, 139-161. doi:10.1007/s10551-001-0784-2

Selsky, J. W., \& Parker, B. (2005). Cross-sector partnerships to address social issues: Challenges to theory and practice. Journal of management, 31(6), 849-873.

https://doi.org/10.1177/0149206305279601

Svendsen, A. C., \& Laberge, M. (2005). Convening Stakeholder Networks. Journal of Corporate Citizenship, (19). doi:10.9974/GLEAF.4700.2005.au.00013

Turner, S., Merchant, K., Kania, J., \& Martin, E. (2012). Understanding the value of backbone organizations in collective impact: Part 2. Stanford Social Innovation Review. Retrieved from https://ssir.org/articles/entry/understanding_the_value_of_backbone_organizations_in_collective _impact_2

U.S. Census. (2015). Quickfacts. Retrieved from https://www.census.gov/quickfacts

Van Bueren, E. M., Klijn, E. H., \& Koppenjan, J. F. (2003). Dealing with wicked problems in networks: Analyzing an environmental debate from a network perspective. Journal of public administration research and theory, 13(2), 193-212. https://doi.org/10.1093/jopart/mug017

Venkataraman, S. (1997). The distinctive domain of entrepreneurship research. Advances in entrepreneurship, firm emergence and growth, 3(1), 119-138. 
Weber, E. P., \& Khademian, A. M. (2008). Wicked problems, knowledge challenges, and collaborative capacity builders in network settings. Public administration review, 68(2), 334349. doi: 10.111/j.1540-6210.2007.00866.x

Yunus, M. (2007). Banker to the Poor. Penguin Books India.

Yunus, M. (2017, August 28). Grameen Bank. Retrieved from http://www.grameeninfo.org/about-us 


\section{Author Information}

Ellen Szarleta is the Director of the Center for Urban and Regional Excellence and Professor in the School of Public and Environmental Affairs at Indiana University Northwest. Her research is focused in the areas of civic engagement, community-university partnerships, public sector decision-making processes, and sustainability.

Ellen Szarleta

Center for Urban and Regional Excellence

School of Public and Environmental Affairs

Indiana University Northwest

3400 Broadway

MP 2117

Gary, Indiana 46408

E-mail: eszarlet@iun.edu

Telephone: 219-980-6698 